\title{
(a)
}

МРНТИ 06.39.41

УДК 005.6

https://doi.org/10.51579/1563-2415.2021-1.39

\section{ВНЕШНИЕ ПРИЧИНЫ НИЗКОЙ РЕЗУЛЬТАТИВНОСТИ СМК БОЛЫШИНСТВА ПРЕДПРИЯТИЙ РЕСПУБЛИКИ КАЗАХСТАН}

А.Б.Токбура, Г.К.Молдашев *, У.А.Торекулова

Университет Международного Бизнеса, Алматы, Казахстан

e-mail: moldashevg@mail.ru

Аннотация. В статье обобщены материаль иироко известных зарубежных и отечественных ученых и экспертов в области прикладной науки «менеджмент качества» по результатам их многолетних исследований (более 30 лет) проблемы влияния различных факторов внешней среды на результативность функиионирования, управления, поддержки и улучиения систем менеджмента качества (СМК) различных организаций, разработанных на основе требований международных стандартов (MC) ISO серии 9000. Установлено, что за последние 10 лет наблюдается устойчивая тендениия снижения уровня мирового рынка услуг по сертификации СМК во всех сферах и отраслях общественного производства и услуг. Многие компании отказываются от сертификации из-за высокой его стоимости и повыпения интенсивности работы с документированной информацией. Аналогичная тенденция падения интереса потребителя к стандартам ISO серии 9000 имеет место и в Казахстане. Так, по наблюдениям авторов статьи в стране количество сертифищированных предприятий по MC ISO на сегодня по сравнению с 2010 годом уменьшилось в два раза. Сделан вывод, что решение проблемы кроется в осознании высшим руководством предприятия, того факта, что дорога к качеству сложна, терниста, бесконечна и нацелена на перманентное улучшение механизмов ведущих к устойчивому развитию и доминированию на рынке на основе MC ISO серии 9000.

Ключевые слова: менеджмент, качество, предприятие, результативность, стандарты ISO, сертификация.

Основные положения и введение. Исследованием и обобщением 30-летнего мирового опыта применения международных стандартов (MC) ISO серии 9000, проведенным техническим комитетом ISO/TC 176 «Менеджмент качества» [1,2], установлены, что 50-90\% предприятий в различных странах внедрили систему менеджмента качества (СМК) формально и не получают от них должной отдачи и реальной пользы:

- так, на сегодня результативность сертифицированных СМК на предприятиях Японии составляет 50, США 40, Западной Европы 30, в странах СНГ 20-10\%, т.е. из сертифицированных в мире 1 миллиона предприятий - 700 тыс. имеют не работающие реально на практике фиктивные, формальные и бумажные СМК;

- с учетом затрат на разработку и сертификацию одного предприятия в год в среднем в размере 15 тыс. долларов, ежегодно выбрасывается на ветер финансовый «пузырь» в объеме 10,5 млрд. долларов (700 тыс. х 15 тыс. $=10,5$ млрд. \$).

В результате на сегодня в мире наблюдается тенденция падения интереса потребителя к стандартам ISO и кризисного их состояния. Поэтому изучение, выявление и устранение причин низкой результативности сертифицированных по MC ISO предприятий - актуальная проблема науки в области менеджмента качества. Содержание статьи будет также интересной в практическом плане для менеджеров, занимающихся разработкой, освоением и внедрением СМК в организациях различных сфер и отраслей экономики страны.

Методы. Для изучения проблемы использовались такие общепринятые в прикладной науке «Менеджмент качества» методы исследования как сбор, наблюдение, сравнение, описание, анализ, синтез и обобщение внешних причин низкой результативности СМК у большинства сертифицированных компаний и фирм страны за последние 10-15 лет, по материалам научных публикаций отечественных и зарубежных ученых и специалистов.

Результаты и обсуждение. По заключению директора Всероссийского НИИ сертификации (ВНИИС), проф. Версана В.Г. [1] к внешним факторам отрицательно влияющим на результативное функционирование СМК предприятий во многих странах относятся:

- «отсутствие в MC ISO серии 9000 методических рекомендаций по интеграции СМК в действующую систему общего менеджмента (COM) предприятия;

- традиционное использование во многих предприятиях и странах даже с развитой экономикой функциональной организационной структуры управления (пирамиды), тогда как процессный подход к менеджменту сочетается с матричной моделью управления».

Аналогичного мнения придерживается один из разработчиков модели Европейской Награды за Качество, итальянский ученый Тито Конти [2]: 
- «одна из причин низкой результативности СМК заключается в MC ISO серии 9000, которые ввели это понятие в науку и практику в отрыве от СОМ предприятия;

- руководители предприятий должны понять, что на фирме не существует отдельной, разобщенной и дезинтегрированной СMК, СЭM, OHSAS, SA, СЭнМ, а есть единая, целостная и интегрированная система менеджмента (ИСМ), составная часть которой - СМК;

- вопрос о переходе предприятий к матричной структуре управления не решается даже самыми передовыми компаниями мира».

Высказывания директора ВНИИС, проф. В.Г.Версана и бывшего президента Европейского общества качества (ЕОК) Т.Конти о совместимости процессного подхода СМК с матричной структурой управления иллюстрирует рисунок 1.

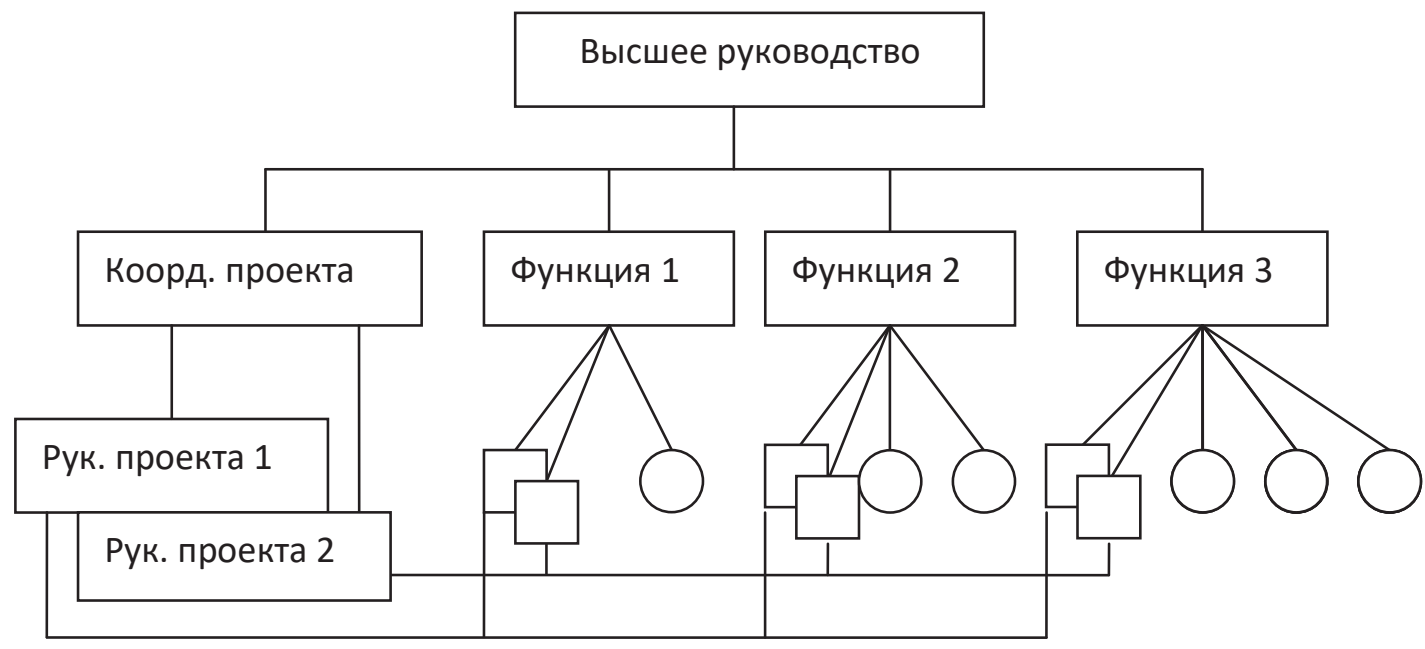

Рисунок 1 - Схема матричной структуры управления

( - исполнители проекта, о-исполнители функции)

Примечание - составлено авторами на основе источников [1,2]

В исследованиях Ю.Т. Шестопал и Н.Ю. Щетининой [3] сделан вывод: «Одной из причин неэффективного менеджмента организации является недопонимание взаимосвязи его функций с функциями СМК».

В результате изложенного, а также в связи с тем, что СМК во многих сертифицированных предприятиях страны на 80-90\% внедрено в административном порядке не ради повышения качества продукции /услуг и процессов деятельности, а ради получения сертификата ISO, моды, рекламы и отчетности перед Правительством, Министерством и Акиматом на местах, то в них на наш взгляд функционируют параллельно и изолировано друг от друга (автономно) две несовместимые, разобщенные и дезинтегрированные системы управления:

- реально используемая, традиционная, административная, вертикальная, функциональная, доминирующая временно, но не документированная по требованиям ISO и унаследованная от советской эпохи, основанная на «праве силы» и эгоизме их высшего руководства;

- новая, горизонтальная, процессная, имитационная и формально созданная для внешних аудиторов и получения сертификата, основанная на «силе правил» и документированная по требованиям MC ISO 9001.

Однако, это временный, неизбежный и болезненный процесс, связанный с необходимостью коренной перестройки менталитета первого руководителя и его трансформации к неформальному лидерству через освоение методологии процессного менеджмента. Так, по мнению директора российского журнала «Стандарты и качество» Н.Г. Томсон [4] «...доморощенный менеджмент без системного подхода к управлению процессами может в мгновенье ока разорить компанию». Для полного освоения процессного менеджмента в сертифицированной организации, по мнению мировых корифеев менеджмента качества (Э.Деминг, Д.Джуран, А.Фейгенбаум, К.Исикава, Г.Тагути и др.), необходимо не менее 10-15 лет. Сократить или продлить эти сроки может только первый руководитель организации, т.к. никто кроме него не сможет обеспечить радикальные изменения менталитета остальных руководителей организации. Для этого, по рекомендации выдающегося американского «гуру» менеджмента П. Друкера [5], «Первый руководитель должен сам олицетворять изменения, которые хочет увидеть в людях».

K тому же MC ISO не догма, а способ организации мышления и всего лишь инструмент создания эффективной системы управления организацией, а не цель которую надо достигнуть любым путем. 
По мнению директора TOO «Euroasia MS» проф. В.И. Соловьева к внешним причинам низкой результативности СМК относятся [6,7]:

- негативные ситуации между участниками бизнес-среды, когда «балом правят агашки», у которых ценностями являются взятки, откаты и т.д.;

- появилась «новая услуга» по продаже фейковых сертификатов соответствия, т.е. «сегодня заказал, а завтра получил» вожделенный сертификат - «однодневку», который имеет в тендерах одинаковый вес в сравнении с организацией, имеющей и поддерживающей зрелую конкурентоспособную систему менеджмента.

Как участники разработки проекта создания «СМК Университета Международного Бизнеса», г.Алматы и имеющие более чем 15-летний опыт его совершенствования, считаем необходимым отметить также следующие внешние факторы, влияющие на её низкую результативность:

- Во-первых, в основной отрасли экономики страны - добыче, разработке, переработке, производстве и реализации нефтегазовых ресурсов - нет конкуренции в том понимании, какое заложено в MC ISO 9001. Однако, в этих условиях оставлять СМК в формальном виде - большой риск вероятности банкротства 70-80\% отечественных предприятий. Поэтому государство должно активно содействовать развитию массового движения за качество менеджмента предприятий.

- В формальных СМК предприятий есть также определенная доля вины отдельных недобросовестных консультантов и аудиторов органа по подтверждению соответствия (ОПС), т.к. они зависимы от своих потребителей и выполняют услуги на платной основе. При этом, консультанты в типе «писаря» и «прислуги», разрабатывающие документацию и процессы СМК предприятия «под ключ» без привлечения топменеджеров, а общающийся только с сотрудниками службы качества уводит предприятие в сторону от построения реальной СМК и заведомо обрекает на неудачу создаваемый проект. В таких организациях как показывает практика возникает конфликт интересов: «верхи» не знают как управлять по новому, а «низы» не хотят работать по старому. При этом «низы» (как правило сильные специалисты) - либо увольняются, либо смиряются с судьбой, но теряют интерес к позитивным изменениям. К тому же, отдельные ОПС в погоне за деньгами и из-за боязни потери клиента, закрывают глаза на факт не освоенности MC ISO серии 9000 в предприятии, продают фейковые сертификаты и комплект документов «под ключ» за 2-3 млн. тенге, строя свой бизнес на их продаже (даже без обучения персонала и диагностического аудита).

Однако не стоит упрекать в таком положении дел лишь консультантов и ОПС, поскольку ответственность консультанта и организации за создание реальной СМК равна 40:60, ибо спасение утопающих дело рук самих утопающих. Консультант и внешние аудиторы в своей деятельности как эксперты СМК общего профиля не в состоянии и не обязаны знать и учитывать специфику, тонкости, нюансы и слабые места всех процессов организации. Они не могут и не имеют морального права давать готовых рецептов улучшения на все случаи жизни и устанавливают только общую схему, каркас, направление и методологию системного управления и развития организации (что делать?). Механизмы и алгоритмы процессов и процедур (как делать?) - должны разрабатывать, адаптируя требования стандартов ISO 9001 к специфике предприятия, а затем, реализовать и улучшать - руководители организации. Поэтому, односторонние усилия здесь не результативны, но качественный консалтинг по внедрению СМК однозначно необходим предприятию.

- Непрерывная организационная чехарда, при которой частая и бессмысленная смена первых руководителей организаций обязательно приводит к радикальной смене их политики, тактики и стратегии менеджмента. В результате ослабляется преемственность поколений и стабильность предприятий, что тормозит завершение многих позитивных начинаний предыдущего руководителя.

- И, конечно, нельзя умолчать, что понятийный аппарат стандартов ISO - туманный, «птичий», непонятный для большинства пользователей. Рекомендации по их применению написаны либо теоретиками в области менеджмента без адаптации требований ISO 9001 на практическую плоскость, либо практиками органов стандартизации или сертификации, имеющими недостаточную базовую теоретическую подготовку в области фундаментального менеджмента. В такой ситуации, требовать от менеджеров эффективного управления предприятием на основе принципов и инструментов системного менеджмента качества не вполне этично и справедливо.

Заключение. Количество предприятий имеющих сертификаты на СМК и другие системы менеджмента (экологии, эргономики, социальной ответственности и энергетики) в Казахстане на начало 2020 г. - 5 тыс. и в последние 5 лет их численность снижается, а живущих по принципам MC ISO 9001:2015 не более 1520\%, из числа сертифицированных. В тоже время, мы не претендуем на абсолютную истинность своих суждений по всем изложенным пунктам. Однако, отрицать реальную действительность не имеет здравого смысла, и не замечать этого - значит закрывать глаза на очевидное, ибо проблема низкой результативности сертифицированных предприятий в стране крайне актуальна, открыто дискутируется в официальной печати и должна найти свое положительное решение на всех уровнях управления. В тоже время, мы априори приняли, что СМК - эффективная система управления предприятием, признанная мировым сообществом. Однако, сле- 
дует знать, что реальная СМК - это состояние духовного развития и корпоративной культуры предприятия и она достигается усилиями всего персонала при коренном изменении его менталитета, а менталитет же наш пока во многих Казахстанских предприятиях соответствует прежнему бытию, т.к. люди подражают всему тому, что заложено в организационную культуру и проповедуется его руководством. Следовательно, для результативной реализации СМК, не хватает пока у высшего руководства предприятий уровня интеллекта, мастерства и культуры, поэтому у нас действует временно закон Ф.М. Достоевского - «искажения великодушных идей» [8].

Таким образом, повышение результативности СМК - извечная, многофакторная и актуальная проблема всех предприятий страны независимо от их размера, формы собственности и состояния экономики. Решение проблемы кроется в осознании руководством предприятий того факта, что дорога к качеству терниста, бесконечна, нацелена на непрерывное улучшение качества ее жизни и осуществлении адекватных действий в соответствии требованиями MC ISO 9001:2015.

\section{Список литетратуры}

1. Версан В.Г. Кризис в стандартизации систем менеджмента. Причины. Пути выхода // Стандарты и качество. 2017. - № 3. - С. 78-83.

2. Конти Т. Кризис в стандартизации СМК должен быть преодолен // Стандарты и качество. 2016. № 9. - С. 78-81.

3. Шестопал Ю.Т., Щетинина Н.Ю. Конкурентоспособность и качество // Стандарты и качество. 2015. - № 2. - C. 62-65.

4. Томсон Н.Г. Лояльный и компетентный // Деловое совершенство. - 2017. - № 2. - С. 3-5.

5. Друкер П. Задачи менеджмента в XX1 веке: учеб. пособие: пер. с англ. - М.: Вильямс, 2012. - 272 с.

6. Соловьев В.И. ISO 9001 - путь к созданию эффективных правил управления организацией // Мир Качества. 2017. - №7. С. 15.

7. Соловьев В.И. Теория и практика менеджмента. Информационно- аналитический портал STANDARD.KZ Общественного объединения «КОКИМ» 2020. www.standard.kz газета Мир качества.

8. www.croguis.ru/2128.html Достоевский М.Ф. - Дневник писателя.

Spisok litetratury

1. Versan V.G. Krizis v standartizacii sistema menedzhemnta. Prichiny. Puti vyxoda, Standarty I kazhestvo, 2017, No. 3, pp. 78-83.

2. Konti T. Krizis v standartizacii SMK dolzhen byt' preodolen, Standarty I kachestvo, 2016, No. 9, pp. 78-81. 2, pp. 62-65.

3. Shestopal Yu.T. Shchetinina N.Yu. Konkurentosposobnost' I kachestvo, Standarty I kachestvo, 2015, No.

4. Tomson N.G. Loyal'nyi I kompetentnyi, Delovoe sovershenstvo, 2017, No. 2, pp. 3-5.

5. Druker P. Zadachi I menedzhementa v XXI veke: ucheb. posobie: per.s angl. - M.: Vil'yams, 2012, 272 pp. 2017, No 7, pp. 15.

6. Solov'ev V.I. ISO 9001 - put' k sozdaniyu effektivnykh pravil upravleniya organizatsiei, Mir Kachestva,

7. Solov'ev V.I. Teoriya I praktika menedzhmenta. Informacionno-analiticheskii portal STANDARD.KZ Obshestvennogo ob'edineniya “KOKIM" 2020. www.standard.kz gazeta Mir kachestva.

8. www.croguis.ru/2128.html Dostoevskii M.F., Dnevnik pisatelya.

\section{«ҚР КӘСІПОРЫНДАРЫНЫН БАСЫМ БӨЛІГІНДЕ СМЖ ТӨМЕН НӘТИЖЕЛІГІНЕ СЫРТКЫ СЕБЕПТЕР}

А.Б. Токбура, Г.К.Молдашев*, У.А.Торекулова

Хальқаральқ Бизнес Университеті, Алматы, Қазақсттан

e-mail: moldashevg@mail.ru

Түйін. Мақалада ISO 9000 серияль хальққаральқ стандарттар негізінде дайындалган кәсіпорындардың СМЖ-н нәтижелілігіне әртүрлі сыртқы орта факторларының әсері жөніндегі мәселелерді зерттеу бойынша отандық және шетелдік авторлардың материалдары жалпьланган. Зерттелген тақырып бойынша еліміздің әртүрлі кәсіпорындары негізінде авторлардың көзқарастары баяндалван. Келелі мәселелерді шешу үшін кәсіпорынның жоварвы басшылывының сапава жету жоль өте күрделі, азапты және шексіз екенін ұвынуы керектігі жөнінде қорытынды жасалван.

Түйінді сөздер: менеджмент, сапа, кәсіпорын, нәтижелілік, ISO стандарттары, сертификаттау. 


\section{EXTERNAL REASONS OF LOW EFFICIENCY OF QMS IN MANY ENTERPRISES OF THE REPUBLIC OF KAZAKHSTAN}

A.B. Tokbura, G.K.Moldashev*, U.A.Torekulova

University of International Business, Almaty, Kazakhstan

e-mail: moldashevg@mail.ru

Summary.The article summarizes the materials of foreign and domestic authors on the research problem related to the influence of various external factors on the effectiveness of the functioning system of the QMS of enterprises, developed on the basis of the international standards ISO 9000 series. The authors' position on the researched topic is presented on the example of various enterprises of the country. It is concluded that the solution of the research problem related to the awareness of the top management system of the enterprise, on the fact that the way to quality system is difficult, thorny and endless.

Key words: management, quality, enterprise, efficiency, ISO standards, certification.

\section{МРНТИ 06.54.41 \\ УДК 330.354}

https://doi.org/10.51579/1563-2415.2021-1.40

\section{ҒЫЛЫМИ-ЗЕРТТЕУ ЖӘНЕ ТӘЖІРИБЕЛІК-КОНСТРУКТОРЛЫҚ ЖҰМЫСТАРЫНЫН ҚАЗАКСТАНДА ИННОВАЦИЯЛЫК ЭКОНОМИКАНЫ ДАМЫТУДАҒЫ РӨЛІ *Ә.Е.Төлепов ${ }^{1}$, А.Б.Тлесова ${ }^{2}$ \\ ${ }^{1}$ Л.Н.Гумилев атындавы Еуразия ұлттық университеті, Нұр-Сұлтан, Қазақстан \\ ${ }^{2}$ М.Өтемісов атындагы Батыс Қазақстан университеті, Орал, Қазақстан *e-mail: adil-tulepov@mail.ru}

Аңдатпа. Мақалада инновациялық экономиканың негізгі компоненттерінің бірі - вылыми-зерттеу және тәжірибелік-конструкторлық жұмыстарының Қазақстандавы даму қарқыны баяндалган. Сонымен қ̧атар, қазіргі таңда әлемде орын алып отырван COVID-19 эпидемиясының елдің инновациялық қъызметіне әсері анықталып, негізгі мәселелерді шешу үшін вылыми-зерттеу және тәжірибелік-конструкторлық жұмыстарды қаржыландыру маңызздылызы дәлелденген. Еліміздегі вылыми-зерттеу және тәжірибелік конструкторлық жұмыстарының негізгі көрсеткіштері талданып, оның қазіргі экономикалық давдарыс уақытында тиімді дамыту ұсыныстары жасалган. Сонымен қатар, инновациялық экономиканы дамытудың, вылыми әзірлемелер мен инноваџиялардың кәсіпорындар және ұйымдармен байланысты қызмет етуінің негізгі мәселелері анықтальп, оларды жетілдіру бойынша ұсынысттар дайындалган. Инновациялық экономиканы қолдау бойынша мемлекеттік саясаттың рөлі және осы бавыттавы шетелдік мемлекеттердің тәжірибесі құарастырылып, оны еліміздің экономикасында қолдану ерекшеліктері баяндалван.

Түйінді сөздер: инноваџияльқ экономика, инновацияльққ қъызмет, COVID-19 пандемиясы, вылымизерттеу және тәжірибелік-конструкторлыққжұмыстар

Негізгі нәтижелер. Мақаланы жазу кезінде келесі негізгі нәтижелерге қол жеткізілді: мемлекеттің инновациялық экономикасын дамытудағы ғылыми-зерттеу және тәжірибелік-конструкторлық жұмыстардың (бұдан әрі - ҒЗТКЖ) маңызы анықталды; Қазақстан Республикасында ҒЗТКЖ дамуының негізгі көрсеткіштерінің серпіні талданды; талдау нәтижелері бойынша еліміздегі инновациялық экономиканың даму қарқыны бағаланды; COVID-19 пандемиясының елдің инновациялық экономикасына тигізетін әсері болжанып, қорытынды жасалды.

Кіріспе. Қазіргі таңда экономикасы дамушы елдер инновациялық қызметін біртіндеп жетілдіру үдерісімен сипатталады. Бұл орайда, бірінші кезекте мемлекеттің және оның жекелеген аймақтарының инновациялық әлеуетін тиімді пайдалану және дұрыс бағалау мәселелері тұрады. Бұл үрдіс Қазақстанның экономикасына да тән. 2015 жылы өткен «Қазақстан - жаңа жаһандық инновациялық хаб» атты халықаралық инновациялық форумында еліміздің Тұңғыш Президенті Нұрсұлтан Әбішұлы Назарбаев атап өткендей: «Экономиканың түрлі салаларында инновацияларды әзірлеу және енгізу біздің мемлекетіміздің дамуының басым стратегиялық бағыттарының бірі болып табылады. Бұл үшін идеяның қалыптасу кезеңінен бастап өндірісте қолдануға дейінгі үрдістерде барлық қажетті жағдайлар қалыптасуда және инновациялық үдерісті қолдаудың қазіргі заманғы инфрақұрылымы құрылуда. Инновациялық белсенділіктің тұрақты өсуі, кәсіпкерлік, ғылым және білім арасындағы үйлесімді қызметтің қалыптасуы шикізаттық экономикадан инновациялық түрге табысты өтудің кепілі болып табылады» [1]. 